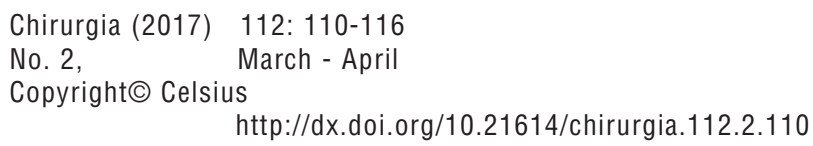

\title{
Hereditary Spherocytosis - Diagnosis, Surgical Treatment and Outcomes. A Literature Review
}

\author{
Simona Manciu ${ }^{1,2}$, Emil Matei ${ }^{1,2}$, Bogdan Trandafir $^{2}$ \\ ${ }^{1}$ Carol Davila University of Medicine and Pharmacy, Bucharest, Romania \\ ${ }^{2}$ Department of General Surgery and Liver Transplantation, Fundeni Clinical Institute, Bucharest, Romania
}

Corresponding author:

Bogdan Trandafir, MD

Department of General Surgery

and Liver Transplantation, Fundeni

Clinical Institute, Bucharest, Romania

E-mail: bogdan21t@gmail.com

\section{Rezumat}

Sferocitoza ereditară - diagnostic, tratament chirurgical și rezultate. $O$ revizie a literaturii

Sferocitoza ereditarã este o maladie congenitalã, caracterizatã prin anemie hemoliticã, ce afecteazã membranele eritrocitelor. Manifestãrile clinice variazã de la forme aproape asimptomatice la forme severe, ce necesitã transfuzii. Diagnosticul se bazeazã pe examenul clinic, hemograma cu numãrul reticulocitelor, prezența unui istoric familial şi teste de laborator specific, cum ar fi testul EMA (eosin-5maleimide binding test) sau testul AGLT (Acidified Glycerol Lysis Time). Splenectomia este consideratã tratamentul standard în formele moderate pânã la severe de boalã. Totuşi, este cunoscut faptul cã splenectomia totalã expune pacientul la complicații infecțioase, uneori letale, ceea ce a determinat indicarea acestei metode cu precauție. Astfel splenectomia subtotalã sau parțialã a devenit o alternativã de tratament fezabilã. Aceasta reduce distrugerea eritrocitelor, în timp ce conservã funcția imunã a splinei. Majoritatea studiilor au arãtat beneficii certe, pe termen scurt, dupã splenectomie, în cazul acestor pacienți. Totuşi, pânã în prezent, rezultate pe termen lung certe, adicã pe o perioadã de peste 5 ani de urmãrire postoperatorie, încã lipsesc.

Cuvinte cheie: sferocite, hemoliză, citometrie în flux, splenectomie, rezultate pe termen lung

Hereditary spherocytosis (HS) is a disease affecting the red blood 
cells membrane and belongs to the congenital hemolytic anemias. The clinical spectrum ranges from asymptomatic patients to severe forms requiring transfusions in early childhood. The diagnosis can be based on the physical examination, complete red blood cell count, reticulocytes count, medical history and specific tests, preferentially the EMA test (eosin-5-maleimide binding) test and AGLT (Acidified Glycerol Lysis Time). Splenectomy is considered the standard surgical treatment in moderate and severe forms of hereditary spherocytosis. Total splenectomy exposes the patient to a life - long risk of potentially lethal infections and thus, its usage was reconsidered. Because of this reason, a feasible alternative is the partial splenectomy. The use of partial splenectomy aims to retain splenic immunologic function, while at the same time to decrease the rate of hemolysis. The long - term outcomes of patients with total or subtotal splenectomy for congenital hemolytic anemia, still remain unclear, but the majority of the studies showed a qualitative resolution of anemia and reduction of transfusion rate. Despite the well known advantages of conservative surgery, the optimal choice of treatment and outcomes should be confirmed with the patient.

Key words: spherocytes, hemolysis, flow cytometry, splenectomy, long-term outcomes

\section{Introduction}

Hereditary spherocytosis (known as MinkowskiChauffard disease) is a heterogeneous group of diseases affecting the red blood cells (1). Clinically, the disease manifests itself depending on the various mutations of genes that encode membrane proteins, their various functional consequences, and the mode of inheritance. (2)

Hereditary spherocytosis belongs to the congenital hemolytic anemias, named after the microscopic aspect of erythrocytes (the cell does not have the usual shape, i.e. spherocytosis means more sphere-shaped), and this change also makes it more fragile than usual, causing its rupture. (3)

In 1900, Oskar Minkowski was the first to describe this disease and published his observations on familial clusters. (4)

\section{Cause}

Commonly, the cause of hereditary spherocytosis is represented by membrane defects. These defects decrease the deformability of the erythrocytes and accelerate their degradation in the spleen (5). The most frequently affected genes are those encoding the membrane proteins ankyrin, band 3 , and spectrin. (6) Modifications of the genes encoding protein 4.2 , the $\mathrm{RH}$ complex and cases with so far undefined defects are less frequent. Seventy percent of all people affected by hereditary spherocytosis suffer from an autosomaldominant trait, while only 15 percent have an autosomal-recessive inheritance. Some patients acquire the disease on account of new mutations. (2)

\section{Clinical presentation}

\section{Symptoms and signs}

The clinical spectrum of hereditary spherocytosis ranges from asymptomatic patients, with incidental diagnosis by laboratory analysis or other indication, to severe forms requiring transfusions in early childhood. (2)

The characteristic features in hereditary spherocytosis are anemia, jaundice, splenomegaly and family history. The typical complications of the disease are those related to cholelithiasis, a consequence of chronic hemolysis and aplastic crisis more frequent after initial infection with Parvovirus B19). (1) The aplastic crisis might lead to dramatic decrease of the hemoglobin concentration and, in this case, a blood transfusion is mandatory. (7)

Another complication that might appear in the mild form of the disease (in patients without splenectomy) is the extramedullary hematopoiesis, with the clinical picture of intrathoracic, 
paravertebral tumors. Elderly patients may also exhibits varicose ulcers. (8)

The association between hereditary spherocytosis and spinocerebellar ataxia was reported in few patients, but it is not known yet whether this association is based on the same genetic defect. (9)

\section{Diagnosis}

A rational diagnostic can be based on physical examination, complete blood cell count, reticulocyte count etc. No single test identifies all forms of hereditary spherocytosis, and that is why it is recommended to combine two test procedures (preferentially the EMA test and AGLT). The typical procedures are found below. (10)

\section{Acidified Glycerol Lysis Test (AGLT)}

The acidified glycerol lysis test (AGLT) is a highly specific method for measuring hemolysis. The sensitivity of the test is $80-95 \%$. The test must be performed within 24 hours after blood sampling or by using samples dispatched by courier (depending on the season, samples must be chilled). (11)

\section{Flow Cytometry (EMA Test)}

This method or the EMA test was introduced quite recently (2000). (11) It is based on the binding of the fluorescent dye eosin-5maleimide to erythrocytes. The binding is decreased in patients with hereditary spherocytosis, as compared with healthy people. (12) The sensitivity of the tests is $90-95 \%$, while its specificity is $95-99 \%$. The result will be valid only if the measurement proceeds within a maximum dwell time of 48 hours between blood sampling and test performance. The binding is increased in cases of stomatocytosis, a hereditary deformation of the erythrocytes which are swollen and cup-shaped, causing congenital hemolytic anemia. (13)

\section{Ektacytometry}

Currently, ektacytometry is a method available only at quite a few sites. The osmotic-gradient ektacytometry determines exactly the osmotic fragility; (therefore, the differentiation between spherocytosis and macrocytic stomatocytosis is possible). The test is reserved to exceptional cases (the diagnosis cannot be obtained otherwise), as it can be performed only with fresh blood taken at the site of analysis.

\section{Membrane analysis}

This analysis can be used both as a quantitative method (by means of gel electrophoresis in order to prove a decrease in the number of membrane proteins) and as qualitative method (in order to identify the affected proteins). However, these methods do not contribute too frequently to diagnosis.

\section{Genetic analysis}

This analysis identifies the genetic defect specific to the patient and/ or the family, but it remains reserved to special cases because of the numerous target genes showing heterogeneity of possible mutations and the considerable related costs.

\section{The role of splenectomy in hereditary spherocytosis}

Splenectomy is considered the standard surgical treatment in moderate and severe forms of hereditary spherocytosis. It is indicated for patients (particularly children), with recurrent hemolytic crisis, significant splenomegaly, severe aplastic crisis, cholelithiasis and developmental delay. These symptoms and signs are recognized to be caused by hemolysis of immature reticulocytes undergoing conditioning in the spleen.

The degree of splenomegaly is the indicator of the severity of anemia and hemolysis. In this case, the surgical approach remains the most attractive option.

Except for the unusual autosomal - recessive variant of hereditary spherocytosis, splenectomy usually eliminates hemolysis and the associated signs and symptoms (15). However, splenectomy does not correct the cytoskeletal membrane defects of hereditary spherocytosis. Thus the erythrocytes are still spheroidal - shaped, with a 
Table 1. Classification of spherocytosis and indications for splenectomy (modified from Bolton-Maggs et al 2011(1); Eber et al, 1990 (14) (copyright 1990 Elsevier)

\begin{tabular}{|c|c|c|c|c|}
\hline & Trait & Mild & Moderate & Severe \\
\hline Haemoglobin $(g / l)$ & normal & $110-150$ & $80-120$ & $60-80$ \\
\hline Reticulocyte count, \% & normal $(<3 \%)$ & $3-6$ & $>6$ & $>10$ \\
\hline Bilirubin $(\mathrm{Imol} / \mathrm{l})$ & $<17$ & $17-34$ & $>34$ & $>51$ \\
\hline $\begin{array}{l}\text { Spectrin molecules per erythrocyte } \\
\text { (\% of normal)* }\end{array}$ & 100 & $80-100$ & $50-80$ & $40-60$ \\
\hline Splenectomy & No required & $\begin{array}{l}\text { Usually not necessary } \\
\text { during childhood }\end{array}$ & $\begin{array}{l}\text { Necessary during } \\
\text { school age before } \\
\text { puberty }\end{array}$ & $\begin{array}{c}\text { Necessary } \\
\text { (delay until } 6 \\
\text { years if possible) }\end{array}$ \\
\hline
\end{tabular}

disorganized membrane ultrastructure, but they are larger (16).

The surgical management of hereditary spherocytosis presumed, historically, total splenectomy. However, total splenectomy exposes the patient to a life - long risk of potentially lethal infections (17) and thus, its usage was reconsidered. In children less than 5 years old, the risk of overwhelming postsplenectomy sepsis may be increased $60^{-}$to 100 fold, compared with that of children without a splenectomy (18)

There are also concerns that despite the immunizations against encapsulated bacteria and the postoperative antibiotic prophylaxis, the risk after total splenectomy is never eliminated. $(17,19,20)$ Because of this reason, a number of alternatives to total splenectomy have been considered, including auto-trans ${ }^{-}$ plantation of the removed spleen and partial splenectomy. (21)

The use of partial splenectomy, particularly in pediatric patients, aims to retain splenic immunologic function, while at the same time to decrease the rate of hemolysis. Partial splenectomy is associated with higher antibody titers

Table 2. Splenectomies for hemolytic anemia* (Fundeni Clinical Institute experience 2002 -2015)

\begin{tabular}{lcc}
\hline Hemolytic anemia & Open approach & 29 \\
\hline No patients -115 & Laparoscopic approach & 30 \\
& Robotic approach & 26 \\
\hline
\end{tabular}

after immunization and better pneumococcal splenic uptake, in comparison to splenic autotransplantation. (22-24)

Several studies have set the minimal amount of the residual parenchyma necessary to maintain adequate phagocytic function, to approximately $15 \%$ of the enlarged spleen. (25-27)

Technically, a splenectomy can be performed either in the traditional open manner or with a minimally invasive approach.

In an open surgery, a partial splenectomy can be safely performed preserving either the upper (28) or the lower pole of the spleen. $(26,29)$

Vasilescu et al $(24,30)$ have shown that preservation of the lower pole of the spleen allows a better mobilization of the splenic remnant, and a more accurate assessment of the volume. The length of the splenic remnant ranged between 3.5 and $6 \mathrm{~cm}$, depending on the initial size of the spleen. In the same study, it was shown that the $15 \%$ target was more difficult to be achieved using the laparoscopic approach, compared with the open surgery, and the evaluation of the remnant spleen was more challenging when the upper pole was preserved.
Table 3. Splenectomies for hereditary spherocytosis* (Fundeni Clinical Institute 2002 -2015)

\begin{tabular}{lcc}
\hline & \multicolumn{2}{c}{ Hereditary spherocytosis } \\
\hline & Children & Adults \\
\hline No patients & 46 & 17 \\
\hline Subtotal splenectomies & 31 & 11 \\
\hline Total splenectomies & 15 & 6 \\
\hline
\end{tabular}


Based on the Vasilescu and co-workers experience in laparoscopy (over 530 minimally invasive splenectomies), over 42 minimally invasive subtotal splenectomies were performed in patients with hereditary microspherocytosis, preserving either the upper or the lower splenic pole.

However, nowadays, the minimally invasive approach has become more attractive and popular, and in most of the experienced centers it is considered the standard of care, because of the important advantages. Thus shorter hospital stay, less postoperative adverse events and better cosmetic outcomes are the main advantages of a minimally invasive approach. (31)

The choice of the blood vessels to be preserved in order to supply the splenic remnant represents a matter of debate. Thus there are mainly two options : to preserve a short gastric artery (32) or a branch of the left gastro epiploic artery (33). However, in some patients the short gastric vessels are too small and too scant or their anatomy is abnormal.

Thus if there is no possibility to use the short gastric vessels or the splenic vessels, the conversion to a total splenectomy is mandatory. Rogulski et al reported 3 patients (out of 15) with intraoperative splenectomy totalization due to the lack of blood supply and ischemia.

Despite of its technical difficulties, laparoscopic subtotal splenectomy is considered the standard surgical treatment in many centers. The laparoscopic approach is safe and effective, while the resection only of a portion of the spleen, provide the limitation of the effects of severe hemolysis combined with the integrity of the innate immune system.

\section{Therapy outcomes}

The long - term outcomes of patients with total or subtotal splenectomy for congenital hemolytic anemia, still remain unclear. The reason is that long - term results are still lacking. Pincez et al reported in 2016 (34), a series of 79 patients from 71 families who underwent subtotal splenectomy for hereditary spherocytosis. To date, this is the largest database of partially splenectomized patients for hereditary spherocytosis, with the longest follow-up (mean follow-up time - 11 years). However, the results of this study should be regarded with caution because of its intrinsic limitations of a single center with a retrospective design. (24)

The majority of the studies from the literature showed a qualitative resolution of anemia and decreased number of reticulocytes. This was a direct result of an increase in the red blood cell lifespan, with values far from normal. In children younger than 6 years old with severe disease, the procedure reduces the transfusion rate and increases the hemoglobin to a level compatible with normal growth and activity. Those benefits varied according to the disease severity. Furthermore, the need for blood transfusions is significantly reduced. This eliminates the associated risks of bloodborne viral infections and iron overload.

Pincez et al (34) showed that $82 \%$ of their patients remained free of any transfusion after splenectomy. However, the hemolytic rate is not abrogated after splenectomy.

As previously reported, the bilirubin level may remain unchanged in some cases, when patients did not undergo cholecystectomy at the time of splenectomy. Residual hemolysis may increase the risk of gallstone formation and some patients may develop cholelithiasis during the follow-up.

In the case of a partial splenectomy, an important concern is the regrowth of the remnant, consistently noted in many previous reports $(25,33,35)$. This disadvantage appears to be more frequently encountered in young children. Nevertheless, partial splenectomy should be considered for those particular patients, because of the immaturity of the immune system. Thus, those patients are not able to make anti - polysaccharide antibodies in response to encapsulated bacteria.

After a total splenectomy, the risk of septicemia associated with meningitis can be as high as $5 \%$, with a mortality risk of $1-5 \%$. (7, 36). Therefore, the indications for a total splenectomy should be restraint to very few cases, while a conservative surgery should be the first option for the largest part of the patients. 
Table 4. The most important studies about hereditary spherocytosis and surgical treatment [after Guizzetti (37)]

\begin{tabular}{llccc}
\hline Study & Study design & Sample size & Period & Splenectomy and procedure \\
\hline Rice et al.(38) & Prospective cohort & 16 & $1993-2000$ & PS, open \\
\hdashline Rice et al. (39) & Retrospective cohort & 19 & $2005-2013$ & PS,mixed \\
\hline Rescorla et al.(40) & Prospective cohort & 111 & $1995-2006$ & TS (mostly), laparoscopy \\
\hline Wood et al.(41) & Institutional case series & 70 & $2000-2008$ & TS, laparoscopy (mostly) \\
\hline Mariani et al.(42) & Institutional case series & 121 & $1980-2008$ & TS, open \\
\hline Abdullah et al.(15) & Retrospective cross-section & 1657 & $1988-2004$ & TS, open \\
\hline
\end{tabular}

The phagocytic function of the remnant spleen can be assessed by scintigraphy, which must show radionuclide uptake in the splenic area. However, pitted erythrocytes, measured by phase microscopy, is considered the gold standard method and is widely available. The normal clinical range is $0-4 \%$, and in case of splenomegaly it may increase to $70 \%$. HowellJolly bodies can also be used, but the method correlates poorly with other measurements.(34) .Pincez et al (34) showed a functional remnant spleen after subtotal splenectomy, in $96 \%$ of their patients. Those patients underwent splenic scintigraphy at one year after surgery, and then every 5 years. Vasilescu et al (7) showed a percentage less than $2 \%$ for pitted erythrocyte in all patients, and transiently Howell-Jolly bodies in 6 of 10 patients, after surgery.

\section{Conclusion}

In conclusion, the resolution of hemolysis, recovery of hemoglobin, prevention or treatment of cholelithiasis, functional remnant splenic assessments, prevention and treatment of possible morbid bacterial infection, are all important issues for the clinician and patient. A lot of studies showed or clarified the expected benefits of conservative surgery in HS. However, the optimal choice of treatment and outcomes should be confirmed with the patient.

\section{References}

1. Bolton-Maggs PHB, Langer JC, Iolascon A, Tittensor P, King M-J, et al. Guidelines for the diagnosis and management of hereditary spherocytosis--2011 update. Br J Haematol. 2012;156(1):37-49. doi: 10.1111/j.1365-2141.2011.08921.x. Epub 2011 Nov 5.

2. Perrotta S, Gallagher PG, Mohandas N. Hereditary spherocytosis. Lancet. 2008;372(9647):1411-26.

3. Inati A, Noun P, Kabbara N, Salloum C, Kmeid M, Sadek M, et al. A multicenter study on the Lebanese experience with hereditary spherocytosis. Pediatr Blood Cancer. 2014;61(10):1895-6. doi: 10.1002/pbc.24992. Epub 2014 Mar 4.

4. Kar R, Rao S, Srinivas UM, Mishra P, Pati HP. Clinico-hematological profile of hereditary spherocytosis: experience from a tertiary care center in North India. Hematology. 2009;14(3):164-7. doi: 10.1179 /102453309X402278.

5. Delaunay J: The molecular basis of hereditary red cell membrane disorders. Blood Rev. 2007;21(1):1-20. Epub 2006 May 30.

6. Da Costa L, Galimand J, Fenneteau O, Mohandas N. Hereditary spherocytosis, elliptocytosis, and other red cell membrane disorders. Blood Rev. 2013;27(4):167-78. doi: 10.1016/j.blre.2013.04.003. Epub 2013 May 9.

7. Vasilescu C, Stanciulea O, Tudor S. Laparoscopic versus robotic subtotal splenectomy in hereditary spherocytosis. Potential advantages and limits of an expensive approach. Surg Endosc. 2012;26(10):2802-9. Epub 2012 Apr 5.

8. Buesing KL, Tracy ET, Kiernan C, Pastor AC, Cassidy LD, Scott JP, et al. Partial splenectomy for hereditary spherocytosis: a multiinstitutional review. J Pediatr Surg. 2011;46(1):178-83. doi: 10.1016 /j.jpedsurg.2010.09.090.

9. Slater BJ, Chan FP, Davis K, Dutta S. Institutional experience with laparoscopic partial splenectomy for hereditary spherocytosis. J Pediatr Surg. 2010;45(8):1682-6. doi: 10.1016/j.jpedsurg.2010. 01.037.

10. Eber SW, Pekrun A, Neufeldt A, Schröter W. Prevalence of increased osmotic fragility of erythrocytes in German blood donors: screening using a modified glycerol lysis test. Ann Hematol. 1992;64(2):88-92.

11. King MJ, Behrens J, Rogers C, Flynn C, Greenwood D, Chambers K. Rapid flow cytometric test for the diagnosis of membrane cytoskeleton-associated haemolytic anaemia. $\mathrm{Br} \mathrm{J}$ Haematol. 2000;111(3):924-33

12. Guitton C, Garçon L, Cynober T, Gauthier F, Tchernia G, Delaunay J, et al. Hereditary spherocytosis: guidelines for the diagnosis and management in children. Arch Pediatr. 2009;16(6):556-8. doi: 10.1016/S0929-693X(09)74065-5. French

13. Guitton C, Garçon L, Cynober T, Gauthier F, Tchernia G, Delaunay J, et al. Hereditary spherocytosis: guidelines for the diagnosis and management in children. Arch Pediatr. 2008;15(9):1464-73. doi: 10.1016/j.arcped.2008.04.023. Epub 2008 Jun 16. French

14. Eber SW, Armbrust R, Schröter W. Variable clinical severity of hereditary spherocytosis: relation to erythrocytic spectrin concentration, osmotic fragility, and autohemolysis. J Pediatr. 1990;117(3):409-16.

15. Abdullah F, Zhang Y, Camp M, Rossberg MI, Bathurst MA, Colombani PM, et al. Splenectomy in hereditary spherocytosis: Review of 1,657 patients and application of the pediatric quality indicators. Pediatr Blood Cancer. 2009;52(7):834-7. doi: 10.1002/pbc.21954. 
16. Li Y, Lu L, Li J. Topological Structures and Membrane Nanostructures of Erythrocytes after Splenectomy in Hereditary Spherocytosis Patients via Atomic Force Microscopy. Cell Biochem Biophys. 2016;74(3):365-71. doi: 10.1007/s12013-016-0755-4. Epub 2016 Aug 24.

17. Kristinsson SY, Gridley G, Hoover RN, Check D, Landgren O. Longterm risks after splenectomy among 8,149 cancer-free American veterans: a cohort study with up to 27 years follow-up. Haematologica. 2014;99(2):392-8. doi: 10.3324/haematol.2013. 092460. Epub 2013 Sep 20.

18. Leonard AS, Giebink GS, BaesI TJ, Krivit W. The overwhelming postsplenectomy sepsis problem. World J Surg. 1980;4(4):423-32.

19. Brigden ML1, Pattullo AL. Prevention and management of overwhelming postsplenectomy infection--an update. Crit Care Med. 1999;27(4):836-42.

20. Rice HE, Oldham KT, Hillery CA, Skinner MA, O'Hara SM, Ware RE. Clinical and hematologic benefits of partial splenectomy for congenital hemolytic anemias in children. Ann Surg. 2003;237(2):281-8.

21. Alvarez FE, Greco RS. Regeneration of the spleen after ectopic implantation and partial splenectomy. Arch Surg. 1980;115(6):772-5.

22. Resende $V$, Petroianu $A$. Functions of the splenic remnant after subtotal splenectomy for treatment of severe splenic injuries. Am J Surg. 2003:185(4):311-5.

23. Petroianu A1, Ferreira VL, Barbosa AJ. Morphology and viability of the spleen after subtotal splenectomy. Braz J Med Biol Res. 1989; 22(4):491-5.

24. Vasilescu C, Stanciulea O, Tudor S, Stanescu D, Colita A, Stoia R, et al. Laparoscopic subtotal splenectomy in hereditary spherocytosis : to preserve the upper or the lower pole of the spleen? Surg Endosc. 2006;20(5):748-52. Epub 2006 Mar 16.

25. Bader-Meunier B, Gauthier F, Archambaud F, Cynober T, Miélot F, Dommergues JP, et al. Long-term evaluation of the beneficial effect of subtotal splenectomy for management of hereditary spherocytosis. Blood. 2001;97(2):399-403.

26. Rice HE, Oldham KT, Hillery CA, Skinner MA, O'Hara SM, Ware RE. Clinical and hematologic benefits of partial splenectomy for congenital hemolytic anemias in children. Ann Surg. 2003;237(2): 281-8.

27. Seshadri PA, Poulin EC, Mamazza J, Schlachta CM. Technique for laparoscopic partial splenectomy. Surg Laparosc Endosc Percutan Tech. 2000;10(2):106-9.

28. Petroianu A. Subtotal splenectomy for treatment of patients with myelofibrosis and myeloid metaplasia. Int Surg. 1996;81(2):177-9.

29. Stoehr GA, Stauffer UG, Eber SW. Near-total splenectomy: a new technique for the management of hereditary spherocytosis. Ann Surg. 2005;241(1):40-7.
30. Vasilescu C, Stănciulea O, Coliță A, Stoia R, Moicean A, Arion C. Laparoscopic subtotal splenectomy in the treatment of hereditary spherocytosis. Chirurgia (Bucur). 2003;98(6):571-6. Romanian

31 Murawski M, Patkowski D, Korlacki W, Czauderna P, Sroka M, Makarewicz W, et al. Laparoscopic splenectomy in children--a multicenter experience. J Pediatr Surg. 2008;43(5):951-4. doi: 10.1016/j.jpedsurg.2007.11.040.

32. Petroianu A. Splenic viability after segmental devascularization. Rev Paul Med. 1992;110(1):39-41.

33. Tchernia G, Gauthier F, Miélot F, Dommergues JP, Yvart J, Chasis JA, et al. Initial assessment of the beneficial effect of partial splenectomy in hereditary spherocytosis. Blood. 1993;81(8):2014-20.

34. Pincez T, Guitton C, Gauthier F, de Lambert G, Picard V, FénéantThibault M, et al. Long-term follow-up of subtotal splenectomy for hereditary spherocytosis: a single-center study. Blood. 2016;127(12): 1616-8. doi: 10.1182/blood-2015-11-679357. Epub 2016 Jan 15.

35. de Buys Roessingh AS, de Lagausie P, Rohrlich P, Berrebi D, Aigrain Y. Follow-up of partial splenectomy in children with hereditary spherocytosis. J Pediatr Surg. 2002;37(10):1459-63.

36. Svarch E, Vilorio P, Nordet I, Chesney A, Batista JF, Torres L, et al. Partial splenectomy in children with sickle cell disease and repeated episodes of splenic sequestration. Hemoglobin. 1996;20(4):393-400.

37 Guizzetti L. Total versus partial splenectomy in pediatric hereditary spherocytosis: A systematic review and meta-analysis. Pediatr Blood Cancer. 2016:63(10):1713-22. doi: 10.1002/pbc.26106. Epub 2016 Jun 14.

38 Rice HE, Oldham KT, Hillery CA, Skinner MA, O'Hara SM, Ware RE. Clinical and hematologic benefits of partial splenectomy for congenital hemolytic anemias in children. Ann Surg. 2003;237(2):281-8.

39. Rice HE, Englum BR, Rothman J, Leonard S, Reiter A, Thornburg $\mathrm{C}$, et al. Clinical outcomes of splenectomy in children: report of the splenectomy in congenital hemolytic anemia registry. Am J Hematol. 2015;90(3):187-92. doi: 10.1002/ajh.23888. Epub 2014 Nov 24.

40. Rescorla FJ1, West KW, Engum SA, Grosfeld JL. Laparoscopic splenic procedures in children: experience in 231 children. Ann Surg. 2007;246(4):683-7; discussion 687-8.

41. Wood JH, Partrick DA, Hays T, Sauaia A, Karrer FM, Ziegler MM. Contemporary pediatric splenectomy: continuing controversies. Pediatr Surg Int. 2011;27(11):1165-71. doi: 10.1007/s00383-0112929-x. Epub 2011 May 28.

42 Mariani M, Barcellini W, Vercellati C, Marcello AP, Fermo E, Pedotti $P$, et al. Clinical and hematologic features of 300 patients affected by hereditary spherocytosis grouped according to the type of the membrane protein defect. Haematologica. 2008;93(9):1310-7. doi: 10.3324/haematol.12546. Epub 2008 Jul 18. 